\title{
The moderating effect of person- organization fit on the relationship between job stress and deviant behaviors of frontline employees
}

\author{
Marliana Junaedi and Fenika Wulani \\ Department of Management, Faculty of Business, \\ Widya Mandala Catholic University, Surabaya, Indonesia
}

Received 23 June 2020

Revised 9 January 2021 22 April 2021

Accepted 27 June 2021

\begin{abstract}
Purpose - The purpose of this paper is to examine the relationship between job stress and deviant behaviors, which include organizational and frontline deviance, and the moderating effect of person-organization (P-O) fit on these relationships.

Design/methodology/approach - The sample consists of 259 frontline employees working in Surabaya, Indonesia. Respondents were asked to complete a questionnaire distributed by survey assistants. This present study conducts partial least squares structural equation modeling to examine hypotheses.

Findings - The results indicate that job stress has positive correlations with organizational and frontline deviance. P-O fit has a moderating effect on the relationship between job stress and frontline deviance; the lower the P-O fit, the stronger the relationship between job stress and frontline deviance. P-O fit does not moderate the relationship between job stress and organizational deviance.

Practical implications - Companies must be more careful in the recruitment and selection process and continuously perform activities to communicate their values and norms to employees.

Originality/value - This study introduces the moderating effect of P-O fit on the relationship between job stress and frontline employees' deviant behaviors, which has not been revealed in previous studies. It provides an understanding of the importance of considering the compatibility between individual and organizational values as one of the company's efforts to reduce stressed employees' responses by engaging in workplace deviance.
\end{abstract}

Keywords Person-organization fit, Job stress, Organizational deviance, Frontline deviance

Paper type Research paper

\section{Introduction}

Organizations certainly have goals to be achieved. Reaching those goals requires high performance and positive work behavior of their employees. However, some types of work demand enormous tasks, culminating stress for employees. This will be prone to stress if their responsibilities lie in between the company and customers, such as frontline employees (Singh, 2000). Since they serve customers as company representatives to interact and communicate with customers (Cambra-fierro et al., 2014; Reynolds and Harris, 2006), they are likely to experience high expectations from their supervisors and verbal aggression from customers (Mulki et al., 2006). Moreover, they are required to provide high-quality service and product knowledge, which brings job stress (Geldart et al., 2018; Sliter et al., 2010). These high demands boost the likelihood of frontline employees experiencing work pressure, which might affect the quality of their services to customers (Kashif et al., 2017; Chaudhary and Lodhwal, 2017).

Job stress is an individual's physical and psychological response when one perceives a threat to something valuable and exhausts his or her resources (Harms et al., 2017). Individuals who experience stress may vent their frustration by taking actions that are detrimental to their organization (De Clercq et al., 2019), such as workplace deviance that targets organizations (Chiu et al., 2015; Bennett and Robinson, 2000) and threatens the well-

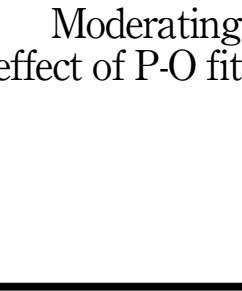

\section{(2)}

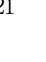


being of their members (Everton et al., 2007). However, since customers can be a source of employee stress, the employee is more likely to retaliate by engaging in deviant behaviors against them (Mullen and Kelloway, 2013). Empirically, there are only a few studies that investigate the effects of job stress on organizational and frontline deviance (e.g. Darrat et al., 2016; Swimberghe et al., 2014). However, these studies provide different results regarding the relationship between job stress and deviant behavior. Darrat et al. (2016) found that job stress (i.e. in specific form: emotional exhaustion) was positively related to organizational and frontline deviance. On the contrary, Swimberghe et al. (2014) discovered that job stress was significantly related to frontline deviance but not organizational deviance. However, they only found a low effect of job stress on frontline deviance.

Little attention has been paid in existing studies to variables that may mitigate or exacerbate the impact of job stress on detrimental work behavior. De Clercq et al. (2019) found that personality factors moderate the relationship between job stress and counterproductive work behavior (CWB). However, they combine targets of CWB, i.e. organization and other individuals. Thus, there is still uncertainty concerning the effect job stress on certain targets. This current study proposes that person-organization (P-O) fit may moderate the relationship between job stress and workplace deviance. Since the latter is employee behavior that violates organizational norms and rules (Robinson and Bennett, 1995), it is possible that P-O fit may reduce the impact of the former. The organization's values play an important role in regulating its employees' behavior (Kim et al., 2013), so individuals with low fit between their values and organization values may have difficulty following the regulations. Thus, it is plausible that individuals with low P-O fit who experience job stress will have a high likelihood of responding with deviant behaviors. Related to the context of frontline employees, since they are expected to communicate the brand image and present themselves as members of the company (Schepers and Nijssen, 2018), the suitability of values between them and the company becomes important. However, the mechanisms of P-O fit's role tend to receive less empirical attention, including in the context of frontline employees.

This study aimed to identify the relationship between job stress and workplace deviance (i.e. organizational and frontline deviance) and the role of P-O fit as a moderating variable in these relationships. We incorporate social exchange theory and conservation of resources theory (COR) as the model's basis. The current study contributes in two ways. First, it provides an understanding of the relationship between job stress and workplace deviance that has not been widely investigated by previous research. We focus on workplace deviance carried out by frontline employees, i.e. in the form of organizational and frontline deviance. This investigation is important considering that frontline employees are the vanguard of the company, so that their deviant behavior may have an impact on the loss of opportunities for the company to gain higher profits. Second, it addresses the research gap regarding the relationship between job stress and workplace deviance and the limited studies investigating factors that can strengthen/weaken the relationship between them. This study offers P-O fit as a moderating variable. We demonstrate that the response of stressed employees by engaging in deviant behavior can be influenced by their P-O fit. Our study not only enriches the literature in regard to the relationship between job stress and workplace deviance, especially in the context of frontline employees, but also provides insights for business practitioners. This study gives guidance to managers to better manage job stress by strengthening employee P-O fit to reduce workplace deviance through various human resource management activities.

\section{Theoretical background and hypothesis}

Job stress, organizational and frontline deviance

Job stress is individuals' responses, both physically and psychologically, that occurs when one's resources are perceived to be insufficient in meeting the expectations for task 
completion (Harms et al., 2017). In the context of stress, these resources can be an object (e.g. socioeconomic status), personal characteristics (e.g. expertise), conditions (e.g. tenure and seniority) and energy (e.g. time and money) that are valuable for individuals (Hobfoll, 1989). Different individuals may have various valuable resources depending on the experience and situation they face (Halbesleben et al., 2014). Job stress can be generated by several triggers, such as work overload and deficient interaction between individuals at work; working conditions, time pressure, family conflicts and interactions with customers; workplace incivility and employee cynicism; organizational politics and workplace victimization and emotional exhaustion (Abubakar et al., 2017, 2018; DeTienne et al., 2012; Geldart et al., 2018; Harms et al., 2017; Jiang et al., 2020). Responses to work stress are called strains: physiological, such as headaches and fatigue; psychological such as anxiety and helplessness (DeTienne et al., 2012; Halbesleben et al., 2014; Hobfoll, 1989; Hobfoll et al., 2018).

COR theory can explain the relationship between job stress and deviant behaviors (Halbesleben et al., 2014; Hobfoll, 1989). The basic principle of COR's is that individuals are motivated to protect existing resources and to obtain new resources (Halbesleben et al., 2014). Furthermore, individuals will engage in certain behaviors to avoid losing their resources (Halbesleben et al., 2014). For example, for the sake of remaining health resources, individuals who have a heavy workload will reduce their effort, which could be considered as deviant behaviors. Furthermore, according to COR theory, individuals focus more on stressors when doing work to protect their resources (Chiu et al., 2015). As a result, they may have deviant behaviors against work norms, such as daydreaming and taking longer breaks. Stressed individuals are prone to frustration and likely to engage harmful behaviors on targets perceived as the sources of frustration, including customers (Chiu et al., 2015; Martinko et al., 2002; and Swimberghe et al., 2014). In various studies, negative individual behaviors that deviate from the norms and rules are investigated in the construct of workplace deviance.

Workplace deviance is an individual's tendency to engage in behavior that violates the workplace's organizational norms (Bennett and Robinson, 2000) and erode the organization values (Mulki et al., 2006). These norms consist of regulations, procedures and policies both formal and informal (Robinson and Bennett, 1995). Deviant behavior can be targeted toward organizations. In this case, individuals engage in actions that violate work norms and rules that result in losses for the company (Ferris et al., 2009; Jelinek and Ahearne, 2010; Malik and Lenka, 2019). For example, employees take company resources without permission and do not carry out their job responsibilities during working hours (Jelinek and Ahearne, 2010), working slowly (Malik and Lenka, 2019). Referring to the indicators provided by Bennett and Robinson (2000), organizational deviance includes such behavior: spent too much time fantasizing or daydreaming instead of working, intentionally working more slowly than you could have worked and put little effort into your work. Additionally, Jelinek and Ahearne (2006) introduced another target, the customers, using the term of frontline deviance. Frontline deviance is a violation of organizational norms that is specifically directed at people outside the organization, such as customers (Jelinek and Ahearne, 2010). Individuals involved in frontline deviant toward customers by conducting unethical and deceptive actions and showing frustration in front of customers (Darrat et al., 2016).

Deviant behaviors are individual's reactions to their experiences in the workplace (Ferris et al., 2009), to the incompatibility between the work situations and individual's expectations (Bordia et al., 2008), as well as organizational stress (Singh, 2019). Individuals who perceive unfavorable events may experience frustration and try to fix the problem or express their feelings toward the organization and its customers (Colbert et al., 2004; Lee and Allen, 2002). This situation is parallel to social exchange theory where individuals tend to unleash unpleasant behaviors due to the bad things they have experienced (Harris et al., 2007). Stressed individuals could view the company as a responsible party. As a result, they will 
engage in behaviors harmful to their company, deviant behaviors against organizations and customers.

However, before individuals perpetrate deviant behaviors, they scrutinize the viability of their actions (Bennett and Robinson, 2000). For frontline employees, it is plausible that these behaviors are directed at the customers they often encounter. Since these frontline employees who experience mental pressure focus more on their problems (Swimberghe et al., 2014), their energy are increasingly drained. Therefore, it is difficult for them to provide satisfactory behaviors or to understand others, which results in harmful and inappropriate interactions with customers (Swimberghe et al., 2014). Empirically, Darrat et al. (2016) found that job stress (i.e. in specific form: emotional exhaustion) was related to salespersons' deviance. Consequently, it can be argued that the higher job stress, the higher individuals' deviant behaviors, and the following hypotheses are proposed:

H1a. Job stress has a positive relationship with organizational deviance.

$H 1 b$. Job stress has a positive relationship with frontline deviance.

$P$-O fit as a moderating effect on the relationship between job stress and deviant behaviors

$\mathrm{P}-\mathrm{O}$ fit is developed based on the interactionist view that individuals' behavior is determined by individuals' characteristics and existing situations (Chatman, 1989). Chatman (1989, p. 339) introduced P-O fit as the congruence between the organization's norms and values and the employee's values. An individual's values refer to one's beliefs about how one should behave or the end-state to be achieved. On the other hand, the values and the norms of the organization are made to regulate its members' behavior, showing which are appropriate (Chatman, 1989). It provides two perspectives: the needs-supplies, referring to companies' ability to meet their employees' needs and the demands-abilities that relates to individuals' ability to meet companies' requirements (Kristof, 1996). Moreover, Kristof (1996) suggested that P-O fit occurs if at least one of the parties, either companies or employees, is capable of meeting the other party's expectations. The existence of P-O fit will affect work attitudes and behavior (Boon and Biron, 2016; Schwepker, 2019). Individuals who have value incompatibility with their company will be more uncomfortable and dissatisfied (Schwepker, 2019). As a result, their social interaction skills will diminish, including when dealing with customers (Matanda and Ndubisi, 2013; Schwepker, 2019). Empirically, Schwepker (2019) found that salespeople who have low P-O fit have reduced quality of services to customers.

Individuals with high P-O fit will have a high sense of belonging to the organizations (Memon et al., 2017). P-O fit has a positive relationship with organizational commitment (Chung, 2017; O'Reilly et al., 1991). Furthermore, organization values are intended to regulate employee behavior (Chung, 2017; Kim et al., 2013). Therefore, if individuals assume that their values are not in line with the company's values, they may have difficulty in exercising organizational values and lack organizational commitment. It can be argued that when individuals with low P-O fit experience stress, they will be unable to follow the organizational rules and norms due to fatigue and too much focus on stress. In addition, the inconvenience of their interpersonal interaction with customers means stressed employees increasingly fail to meet applicable service norms, so they are involved in frontline deviance. Their low organizational commitment and sense of belonging also make it easier for them to disobey organizational rules and provide inadequate performance, especially when they experience intense tension. Hence, this current study proposes that

H2a. The relationship between job stress and organizational deviance is moderated by $\mathrm{P}-\mathrm{O}$ fit, such that the relationship is stronger when $\mathrm{P}-\mathrm{O}$ fit is low than high. 
H2b. The relationship between job stress and frontline deviance is moderated by P-O fit, such that the relationship is stronger when P-O fit is low than high.

\section{Method}

\section{Sample and data collection}

This study uses a self-report questionnaire distributed to the respondents by survey assistants. The respondents are frontline employees who work as salespeople, customer service and bank tellers from various industries in Surabaya, Indonesia. Surabaya is the capital of East Java and a business center in Indonesia (Gilbert, 2017). Selection of respondents based on purposive sampling technique (i.e. nonmanagerial and educational level). We asked the respondents to fill out the questionnaire anonymously and return it within a sealed envelope that was already provided. There are 259 surveys collected, which could be analyzed for hypothesis testing. The respondents' profiles demonstrate that the majority of the respondents are women (58.3\%) with the age range of $18-35$ years old $(90.8 \%)$, have tenure $<5$ years $(81.4 \%)$ and are single $(68.7 \%)$.

\section{Instrument}

$\mathrm{P}-\mathrm{O}$ fit is an individual's perception of the congruence between the organizational values and his/her values. In this study, P-O fit was measured using five indicators that we adopted from Netemeyer et al. (1997) (e.g. This organization has the same values as I do with regard to concern for others) and Saks and Ashforth (1997) (e.g. I feel like I really match into my organization). Respondents were asked to respond on a 5 -point Likert scale $(1=$ strongly disagree, $5=$ strongly agree). Job stress is a condition of physical and psychological disorders experienced by individuals due to work pressure accumulated from preceding years. Work stress was measured using seven indicators (e.g. I feel emotionally drained from my work) from Anderson et al. (2002). Respondents were asked to respond on a 5-point Likert scale $(1=$ never, 5 = every day). Organizational deviance is an individual's deviant behavior toward the company, while frontline deviance is an individual's deviant behavior toward the customers in the prior year. This study used 12 organizational deviance indicators (e.g. Spent too much time fantasizing or daydreaming instead of working) from Bennett and Robinson (2000), and three frontline deviance indicators (e.g. Acted out work-related frustrations in front of a customer) from (Darrat et al., 2016). Respondents were asked to respond to both deviant behaviors on a 5 -point Likert scale $(1=$ never, $5=$ daily). The research questionnaire was modified and translated into Indonesian to facilitate respondents' understanding. To minimize the potential of $\mathrm{CMB}$, we asked respondents to complete the questionnaire anonymously and return it in a sealed envelope (Abubakar et al., 2017; Podsakoff et al., 2003).

\section{Result \\ Measurement model and hypotheses testing}

This study conducts data analysis in three stages, namely, identifying the common method variance, testing the measurement model and finally, testing the research hypothesis. Based on Harman's single factor test (Podsakoff et al., 2003), the largest variance explained by the first factor is $25.22 \%$, indicating the absence of a single factor. Therefore, common method bias is not a potential threat for this study.

This study examines the validity, reliability and hypotheses using partial least squares structural equation modeling, which is illustrated in Figure 1. Table 1 exhibits composite reliability (CR) values and convergent validity (i.e. outer loading values and average variance extracted [AVE]). For the achievement of sufficient convergent validity, several indicators are dropped and are not used in further analysis. All outer loading of each indicator results in 


\begin{tabular}{|c|c|c|c|c|c|}
\hline \multirow{8}{*}{ IJWHM } & Variables & Item & Loading & $\mathrm{CR}$ & $\mathrm{AVE}$ \\
\hline & \multirow[t]{7}{*}{ Job stress (JS) } & JS1 & 0.671 & \multirow[t]{7}{*}{0.882} & \multirow[t]{7}{*}{0.521} \\
\hline & & JS2 & 0.76 & & \\
\hline & & JS3 & 0.791 & & \\
\hline & & JS4 & 0.843 & & \\
\hline & & JS5 & 0.562 & & \\
\hline & & JS6 & 0.754 & & \\
\hline & & JS7 & 0.635 & & \\
\hline & \multirow[t]{3}{*}{ Frontline deviance (FD) } & FD1 & 0.82 & \multirow[t]{3}{*}{0.836} & \multirow[t]{3}{*}{0.629} \\
\hline & & FD2 & 0.748 & & \\
\hline & & FD3 & 0.81 & & \\
\hline & \multirow[t]{8}{*}{ Organizational deviance (OD) } & OD2 & 0.755 & \multirow[t]{8}{*}{0.892} & \multirow[t]{8}{*}{0.509} \\
\hline & & OD4 & 0.774 & & \\
\hline & & OD5 & 0.744 & & \\
\hline & & OD6 & 0.696 & & \\
\hline & & OD7 & 0.678 & & \\
\hline & & OD8 & 0.798 & & \\
\hline & & OD11 & 0.664 & & \\
\hline & & OD12 & 0.574 & & \\
\hline & \multirow[t]{5}{*}{ Person-organization (P-O) fit } & PO1 & 0.679 & \multirow[t]{5}{*}{0.892} & \multirow[t]{5}{*}{0.626} \\
\hline & & $\mathrm{PO} 2$ & 0.782 & & \\
\hline Table 1. & & $\mathrm{PO} 3$ & 0.864 & & \\
\hline Reliability and & & $\mathrm{PO} 4$ & 0.889 & & \\
\hline convergent validity & & PO5 & 0.721 & & \\
\hline
\end{tabular}

Figure 1.

Research model

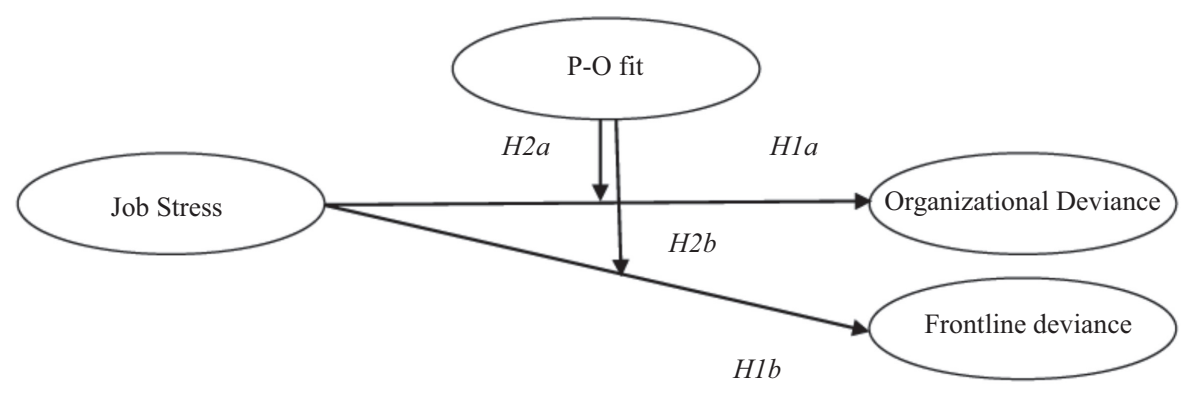

values above the minimum cutoff of 0.5 (Hair et al., 2017). Similarly, the test of convergent validity at the construct level can be seen from each variable's AVE value, which also has the minimum cutoff of 0.5 (Hair et al., 2017). As a condition to fulfill the reliability of internal consistency, all variables have shown satisfactory CR values, being more than 0.836 (Hair et al., 2017). Furthermore, the Heterotrait-Monotrait (HTMT) ratio of correlations approach is used for discriminant validity testing. Table 2 shows that all the constructs have a value less than HTMT.85 (Hair et al., 2017), which indicates that they are unique constructs.

\section{Structural model}

Table 3 shows that job stress is positively correlated to organizational deviance $(\beta=0.359$, $p<0.01)$ and to frontline deviance $(\beta=0.257, p<0.01)$. These results support hypotheses 1a and $1 \mathrm{~b}$. Although not hypothesized, but as part of the moderation testing process, this study found that $\mathrm{P}-\mathrm{O}$ fit has a negative effect on organizational and frontline deviance (respectively: 
$\beta=-0.209, p<0.01 ; \beta=-0.169, p<0.01)$. Moreover, testing the role of moderation indicates that $\mathrm{P}-\mathrm{O}$ fit moderates the relationship between job stress and frontline deviance $(\beta=-0.242$, $p<0.05)$ but does not moderate the relationship between job stress and organizational deviance $(\beta=-0.089$, ns.). These results support hypothesis $2 \mathrm{~b}$ but do not support hypothesis $2 \mathrm{a}$. Figure 2 displays the correlation between job stress and frontline deviance is stronger as the P-O fit decreased, and that job stress is not significantly correlated to frontline deviance when $\mathrm{P}-\mathrm{O}$ fit is high.

\section{Discussion}

As predicted, the results show that job stress is positively correlated to organizational and frontline deviance. These results are in line with the COR theory. Stressed individuals are engulfed in their resources and tend to focus on the causes of stress and their poor condition. Consequently, they may reduce their efforts to protect their remaining resources. Another explanation is that they may show undue performance in front of customers because of their

\begin{tabular}{lllll}
\hline Variables & JS & FD & OD & P-O fit \\
\hline
\end{tabular}
(1) JS
(2) FD
(3) OD
0.393
(4) P-O fit
0.83
0.45
0.243
0.181
0.252

Table 2.

Note(s): $n=259$

Note(s): $n=259$

\begin{tabular}{llccl}
\hline Hypothesis & Relationship & Path coefficient & $t$ & Hypothesis support \\
\hline H1a & JS $\rightarrow$ OD & 0.359 & $6.689^{* * *}$ & Supported \\
H1b & JS $\rightarrow$ FD & 0.257 & $4.738^{* *}$ & Supported \\
H2a & POF $\times$ JS $\rightarrow$ OD & -0.089 & 0.631 & Unsupported \\
H2b & POF $\times$ JS $\rightarrow$ FD & -0.242 & $2.165^{*}$ & Supported
\end{tabular}

Note(s): $* * p<0.01 ; p<0.05$

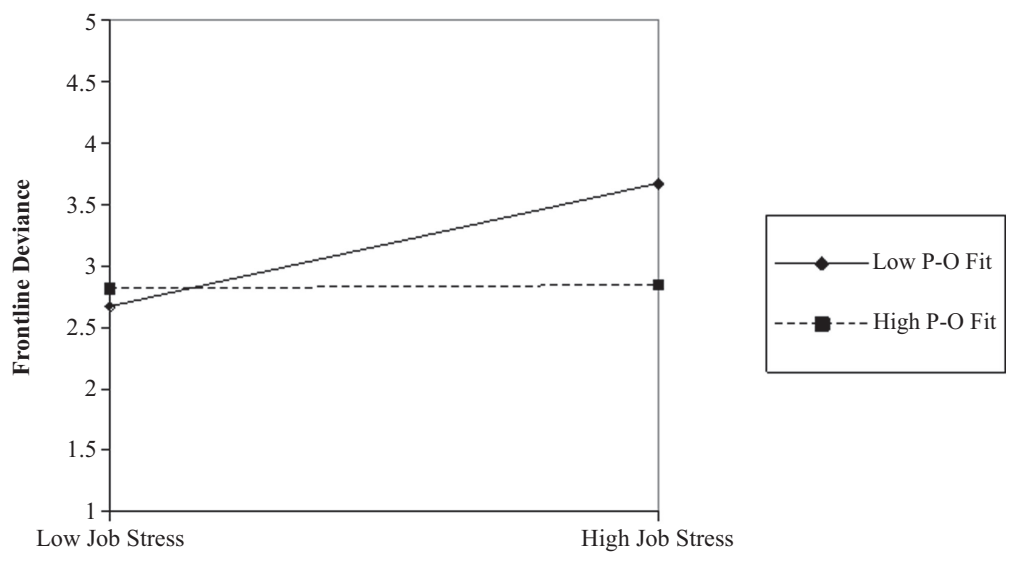

Figure 2.

Moderation effect of P-O fit 
fatigue. Our result can also be explained based on the social exchange theory that individuals deviate from the norm to retaliate organizations and customers who are considered to be the cause of their unpleasant conditions. Referring to our sample, frontline employees may experience work stress due to high work demands and the provision to interact with customers. This type of work requires them to have high product knowledge and a certain level of service quality in order to satisfy customers, boosting company sales. The stressed frontline employee exhibits heightened deviant behaviors toward the organization and customers. The impacts of these behaviors could be detrimental to the company, decreasing organizational performance and escalating customers' dissatisfaction.

Our findings support Darrat et al. (2016) about the relationship between job stress and workplace deviance. However, in contrast to this current study which focuses on the physical and psychological conditions of employees who experience stress, Darrat et al. (2016) focused on the impact of emotional exhaustion. Thus, the results of this study enrich the literature regarding the relationship between job stress and deviant behaviors, i.e. organizational and frontline deviance, especially in the context of frontline employees, which has not been widely studied. These findings support several studies that employees experiencing unpleasant and stressful conditions will respond by engaging in behavior that deviates from workplace norms and rules, such as intention to sabotage (Abubakar and Arasli, 2016), job search behavior (Abubakar et al., 2018), workplace withdrawal behavior (Abubakar et al., 2017) and organizational deviance (Chung, 2017; Khattak et al., 2019, 2020). These studies were conducted in different countries that have different cultural contexts. These findings indicate that, in general, individuals who experience unpleasant events will respond by engaging in deviant behavior. This thinking is in line with Cropanzano and Mitchell (2005) that social exchange theory can be applied universally even though the cultural context can still influence the extent to which individuals apply this reciprocal principle.

Further analysis reveals that P-O fit moderates the relationship between job stress and frontline deviance. There is a strong positive correlation between job stress and frontline deviance when P-O fit is low. Contrarily, when P-O fit is high, the relationship between job stress and frontline deviance is not significant. Incongruent values between the organization and employees will encourage the emergence of counterproductive attitudes and behaviors (Schwepker, 2019). Individuals who have a value match with their organization will trust their company and be comfortable in interpersonal interactions in the workplace (Cable and Edwards, 2004; Zhang and Bloemer, 2008). Thus, frontline employees with low P-O fit may become less comfortable communicating and becoming agents of the company's brand. The work stress they experience makes them run out of important resources to serve customers. Especially with the lower P-O fit, they will be increasingly uncomfortable and unable to become a qualified service provider who must communicate the company's value through the products and brands they offer to customers. As a result, stressed frontline employees will increasingly exhibit frontline deviance. In addition, Matanda and Ndubisi (2013) suggest that individuals who have similar values as their organizations are more likely to provide the same service value to customers. Furthermore, individuals who have value incongruence with their company will experience job dissatisfaction (Kim et al., 2013), which makes them unable to satisfy their customers (Matanda and Ndubisi, 2013). Therefore, the absence of compatibility can strengthen the adverse impact work stress on frontline deviance.

However, this present study shows that P-O fit does not mitigate/exacerbate the impact of job stress on organizational deviance. There are several possible explanations regarding this result. Individuals who engage in workplace deviance may consider the risks of that behavior (Diefendorff, 2007). Some employees might consider organizational deviance to be too risky to carry out, while others do not. In this case, the compatibility between the individuals' values and the organizations' may not be relevant in limiting their involvement in organizational deviance. For some individuals, organizational deviance is still carried out despite their value 
fit because they feel that the organization fails to establish a pleasant working environment and is less concerned about employees' psychological and physiological health. As a result, individuals who experience job stress may perceive the organization as responsible for their stresses. These employees respond to their frustration by defying organization norms. On the contrary, other employees, regardless of having high or low P-O fit, tend to focus on exercising frontline deviance as opposed to organizational deviance since they consider customers as the cause of their stress.

\section{Implication}

Because of their job demands, frontline employees are vulnerable to stress. As a result, they can respond to their stress through workplace deviance. Undeniably, these employees are more likely to be involved in deviant behavior if they have low P-O fit. P-O fit is important to pay attention to because individuals who have a value mismatch with those of their company will be more uncomfortable and dissatisfied (Schwepker, 2019). As a result, their social interaction skills will decrease, including when dealing with customers (Matanda and Ndubisi, 2013; Schwepker, 2019). Schwepker (2019) found that salespeople who have a low $\mathrm{P}$-O fit have lowered the quality of service to customers. Our study also shows that employees who have a low P-O fit will increasingly respond to their job stress by engaging in workplace deviance. Since individual characteristics and situational factors can influence the extent to which individuals experience and react to their stress by engaging in deviant behavior (Malik and Lenka, 2019; Singh, 2019), organizations need to improve effective employee management practices to reduce the risk of improper employee placement and unpleasant situations. Therefore, companies and managers need to consider the following approach to manage their employees successfully based on human resource practices.

First, the interactionist approach suggests that companies need to prevent this issue by exercising the process of selection and continuous socialization to control employees' behavior (Chatman, 1989). During the recruitment and selection process, companies should be more careful in assessing applicants' personalities, such as reflecting whether individuals have values parallel to the company and their job, the tendency to experience stress and the likelihood of rules violation. Background checks and references are essential in recruiting individuals with minimized likelihood of engaging in workplace deviance. Second, companies need to continuously support, establish friendly relationships and develop participatory decision-making processes with employees to reduce their work stress and deviant behaviors. Moreover, since individual differences (e.g. disposition) can play a role in how individuals deal with pressures at work (Barsky et al., 2004), organizations need to provide information about company demands for employee work behavior and work conditions. Organizations also need to consider situational factors that may increase employees' stressful experiences, such as supervisors and coworkers' behavior (Cohen and Wills, 1985). In this regard, they need to create a comfortable social environment and hold role-playing training so colleagues and supervisors can understand the impact of their negative behavior. Third, employees can learn the company's values and norms from the daily activities they experience, including how managers treat them (Lu et al., 2015; Zheng et al., 2017). Therefore, companies need to evaluate regularly to ensure that managers have become positive role models and treat their employees according to company values and norms. Fourth, companies need to communicate their values, norms and regulations regularly to all organization members while also providing a clear reward and punishment policy to reduce deviant behavior.

\section{Conclusion}

This study found that frontline employees who experience work stress may engage in deviant behavior. This can be directed toward the organization, such as frequent 
daydreaming, and customers, in the form of unethical conduct. These behaviors certainly reduce the overall effectiveness of the organization and intensify customers' dissatisfaction level which leads to the deterioration of the organization's performance. Furthermore, this study demonstrates that the impact of job stress on frontline deviance can be exacerbated if employees have low P-O fit. Therefore, companies need to emphasize not only the suitability between individual competencies and job requirements but also that between an individual's values and those of the organization.

Despite these contributions, this study contains limitations that need to be addressed in future studies. First, this study uses cross-sectional data. Future researchers should consider using longitudinal studies, specifically related to the possibility of a change in P-O fit due to work stress. By using longitudinal study, researchers may compare the changes in research subjects after a certain period. The stages can be done as follows: $\mathrm{P}-\mathrm{O}$ fit is analyzed in Time 1 and Time 3; job stress is analyzed in Time 2. This research was conducted on the same subjects, and each period was given a time lag. Thus, it will appear that there is a change in the employees' P-O Fit due to their job stress. Second, this study obtained data through self-report for all variables. Since these variables - job stress and P-O fit - are subjective to personal perceptions and personal experience, self-report could be an alternative way to obtain data. Furthermore, Berry et al. (2007) indicated no significant difference in the use of self-reports or other reports to measure individuals' deviant behaviors. However, the use of other data sources is suggested for future researches. Third, since individuals may work in fields that are not in accordance with their wishes, including their skills and abilities (person-job [P-J] fit), further studies need to consider the role of this P-J fit variable as a moderation in the relationship between job stress and deviant behavior. Furthermore, draw from the results that P-O Fit does not moderate the relationship between job stress and organizational deviance, future research may test moderating variables such as organizational characteristics, employee characteristics and workgroups (Appelbaum et al., 2007), which may play a role in this relationship. Social support from co-workers and supervisors can mitigate individuals who experience unpleasant treatment to engage in behaviors detrimental to the organization (Holm et al., 2019). Future studies may identify the role social support has as a moderating effect on the relationship between job stress and workplace deviance. Fourth, the sample of this study is the frontline employees. Further studies should consider utilizing other occupations with a code of ethics that requires high professional work, such as doctors and teachers. Therefore, future research regarding this context could generate more generalized outcomes.

\section{References}

Abubakar, A.M. and Arasli, H. (2016), "Dear top management, please don't make me a cynic: intention to sabotage", Journal of Management Development, Vol. 35 No. 10, pp. 1266-1286.

Abubakar, A.M., Namin, B.H., Harazneh, I., Arasli, H. and Tunç, T. (2017), "Does gender moderates the relationship between favoritism/nepotism, supervisor incivility, cynicism and workplace withdrawal: a neural network and SEM approach”, Tourism Management Perspectives, Vol. 23, pp. 129-139.

Abubakar, A.M., Megeirhi, H.A. and Shneikat, B. (2018), “Tolerance for workplace incivility, employee cynicism and job search behavior", Service Industries Journal, Vol. 38 Nos 9-10, pp. 629-643.

Anderson, S.E., Coffey, B.S. and Byerly, R.T. (2002), "Formal organizational initiatives and informal workplace practices: links to work - family conflict and job-related outcomes", Journal of Management, Vol. 28 No. 6, pp. 787-810.

Appelbaum, S.H., Iaconi, G.D. and Matousek, A. (2007), "Positive and negative deviant workplace behaviors: causes, impacts, and solutions", Corporate Governance, Vol. 7 No. 5, pp. 586-598.

Barsky, A., Thoresen, C.J., Warren, C.R. and Kaplan, S.A. (2004), "Modeling negative affectivity and job stress : a contingency-based approach”, Journal of Organizational Behavior, Vol. 25, pp. 915-936. 
Bennett, R.J. and Robinson, S.L. (2000), "Development of a measure of workplace deviance", Journal of Applied Psychology, Vol. 85 No. 3, pp. 349-360.

Berry, C.M., Ones, D.S. and Sackett, P.R. (2007), "Interpersonal deviance, organizational deviance, and their common correlates: a review and meta-analysis", Journal of Applied Psychology, Vol. 92 No. 2, pp. 410-424.

Boon, C. and Biron, M. (2016), "Temporal issues in person-organization fit, person-job fit and turnover: the role of leader-member exchange”, Human Relations, Vol. 69 No. 12, pp. 2177-2200.

Bordia, P., Restubog, S.L.D. and Tang, R.L. (2008), "When employees strike back: investigating mediating mechanisms between psychological contract breach and workplace deviance", Journal of Applied Psychology, Vol. 93 No. 5, pp. 1104-1117.

Cable, D.M. and Edwards, J.R. (2004), "Complementary and supplementary fit: a theoretical and empirical integration”, Journal of Applied Psychology, Vol. 89 No. 5, pp. 822-834.

Cambra-fierro, J., Melero-polo, I. and Vázquez-carrasco, R. (2014), "The role of frontline employees in customer engagement", Revista Espanola de Investigacion En Marketing, Vol. 18 No. 2, pp. 67-77.

Chatman, J.A. (1989), "Improving interactional organizational research: a model of person-organization fit”, The Academy of Management Review, Vol. 14 No. 3, p. 333.

Chaudhary, P. and Lodhwal, R.K. (2017), "An analytical study of organizational role stress (ORS) in employees of nationalized banks: a case of Allahabad Bank", Journal of Management Development, Vol. 36 No. 5, pp. 671-680.

Chiu, S., Yeh, S. and Huang, T.C. (2015), "Role stressors and employee deviance : the moderating effect of social support”, Personnel Review, Vol. 44 No. 2, pp. 308-324.

Chung, Y.W. (2017), "The role of person-organization fit and perceived organizational support in the relationship between workplace ostracism and behavioral outcomes", Australian Journal of Management, Vol. 42 No. 2, pp. 328-349.

Cohen, S. and Wills, T.A. (1985), "Stress, social support, and the buffering hypothesis", Psychological Bulletin, Vol. 98 No. 2, pp. 310-357.

Colbert, A.E., Mount, M.K., Harter, J.K. and Barrick, M.R. (2004), "Interactive effects of personality and perceptions of the work situation on workplace deviance", Journal of Applied Psychology, Vol. 89 No. 4, pp. 599-609.

Cropanzano, R. and Mitchell, M.S. (2005), "Social exchange theory: an Interdisciplinary review", Journal of Management, Vol. 31 No. 6, pp. 874-900.

Darrat, M., Atinc, G. and Babin, B.J. (2016), "On the dysfunctional consequences of salesperson exhaustion", Journal of Marketing Theory and Practice, Vol. 24 No. 2, pp. 236-245.

De Clercq, D., Haq, I.U. and Azeem, M.U. (2019), "Time-related work stress and counterproductive work behavior: invigorating roles of deviant personality traits", Personnel Review, Vol. 48 No. 7 , pp. 1756-1781.

DeTienne, K.B., Agle, B.R., Phillips, J.C. and Ingerson, M.C. (2012), "The impact of moral stress compared to other stressors on employee fatigue, job satisfaction, and turnover: an empirical investigation", Journal of Business Ethics, Vol. 110 No. 3, pp. 377-391.

Diefendorff, J.M. (2007), "The relations of motivational traits with workplace deviance", Journal of Applied Psychology, Vol. 92 No. 4, pp. 967-977.

Everton, W.J., Jolton, J.A. and Mastrangelo, P.M. (2007), "Be nice and fair or else: understanding reasons for employees' deviant behaviors", Journal of Management Development, Vol. 26 No. 2, pp. 117-131.

Ferris, D.L., Brown, D.J. and Heller, D. (2009), "Organizational supports and organizational deviance : the mediating role of organization-based self-esteem", Organizational Behavior and Human Decision Processes, Vol. 108 No. 2, pp. 279-286.

Ferris, G.R., Liden, R.C., Munyon, T.P., Summers, J.K., Basik, K.J. and Buckley, M.R. (2009), "Relationships at work:Toward a multidimensional conceptualization of dyadic work relationships", Journal of Management, Vol. 35 No. 6, pp. 1379-1403. 
Geldart, S., Langlois, L., Shannon, H.S., Cortina, L.M., Griffith, L. and Haines, T. (2018), "Workplace incivility, psychological distress, and the protective effect of co-worker support", International Journal of Workplace Health Management, Vol. 11 No. 2, pp. 96-110.

Gilbert, K. (2017), "Biggest cities in Indonesia", World Atlas, available at: http://www.worldatlas.com/ articles/biggest-cities-in-indonesia.html (accessed 21 June 2020).

Hair, J., Hult, G.T.M., Ringe, C.M. and Sarstedt, M. (2017), A Primer on Partial Least Squares Structural Equation Modeling (PLS-SEM), 2nd ed., Sage, California.

Halbesleben, J.R.B., Neveu, J.P., Paustian-Underdahl, S.C. and Westman, M. (2014), "Getting to the 'COR': understanding the role of resources in conservation of resources theory", Journal of Management, Vol. 40 No. 5, pp. 1334-1364.

Harms, P.D., Credé, M., Tynan, M., Leon, M. and Jeung, W. (2017), "Leadership and stress : a metaanalytic review", The Leadership Quarterly, Vol. 28 No. 1, pp. 178-194.

Harris, K.J., Kacmar, K.M. and Zivnuska, S. (2007), "An investigation of abusive supervision as a predictor of performance and the meaning of work as a moderator of the relationship", The Leadership Quarterly, Vol. 18, pp. 252-263.

Hobfoll, S.E. (1989), "Conservation of resources: a new attempt at conceptualizing stress", American Psychologist, Vol. 44 No. 3, pp. 513-524.

Hobfoll, S.E., Halbesleben, J., Neveu, J.-P. and Westman, M. (2018), "Conservation of resources in the organizational context: the reality of resources and their consequences", Annual Review of Organizational Psychology and Organizational Behavior, Vol. 5 No. 1, pp. 103-128.

Holm, K., Torkelson, E. and Bäckström, M. (2019), "Exploring links between witnessed and instigated workplace incivility", International Journal of Workplace Health Management, Vol. 12 No. 3, pp. 160-175.

Jelinek, R. and Ahearne, M. (2006), "The enemy within: examining salesperson deviance and its determinants", Journal of Personal Selling and Sales Management, Vol. 26 No. 4, pp. 327-344.

Jelinek, R. and Ahearne, M. (2010), "Be careful what you look for: the effect of trait competitiveness and long hours on salesperson deviance and whether meaningfulness of work matters", The Journal of Marketing Theory and Practice, Vol. 18 No. 4, pp. 303-321.

Jiang, H., Jiang, X., Sun, P. and Li, X. (2020), "Coping with workplace ostracism: the roles of emotional exhaustion and resilience in deviant behavior", Management Decision, Vol. 59 No. 2, pp. 358-371.

Kashif, M., Braganca, E., Awang, Z. and Cyril De Run, E. (2017), "You abuse but I will stay: the combined effects of job stress, customer abuse, and emotional intelligence on employee turnover", Journal of Management Development, Vol. 36 No. 7, pp. 899-914.

Khattak, M.N., Khan, M.B., Fatima, T. and Shah, S.Z.A. (2019), "The underlying mechanism between perceived organizational injustice and deviant workplace behaviors: moderating role of personality traits", Asia Pacific Management Review, Vol. 24 No. 3, pp. 201-211.

Khattak, M.N., Zolin, R. and Muhammad, N. (2020), "The combined effect of perceived organizational injustice and perceived politics on deviant behaviors", International Journal of Conflict Management, Vol. 32 No. 1, pp. 62-87.

Kim, T.Y., Aryee, S., Loi, R. and Kim, S.P. (2013), "Person-organization fit and employee outcomes: test of a social exchange model”, International Journal of Human Resource Management, Vol. 24 No. 19, pp. 3719-3737.

Kristof, A.L. (1996), "Person-organization fit: an integrative review of its conceptualizations, measuremen, and implications", Personnel Psychology, Vol. 49, pp. 1-49.

Lee, K. and Allen, N.J. (2002), "Organizational citizenship behavior and workplace deviance: the role of affect and cognitions", Journal of Applied Psychology, Vol. 87 No. 1, pp. 131-142.

Lu, S., Bonfrer, A. and Voola, R. (2015), "Retaining talented salespeople", Customer Needs and Solutions, Vol. 2 No. 2, pp. 148-164. 
Malik, P. and Lenka, U. (2019), "Identifying HRM practices for disabling destructive deviance among public sector employees using content analysis", International Journal of Organizational Analysis, Vol. 28 No. 3, pp. 719-744.

Martinko, M.J., Gundlach, M.J. and Douglas, S.C. (2002), "Toward an integrative theory of counterproductive workplace behavior: a causal reasoning perspective", International Journal of Selection and Assessment, Vol. 10 Nos 1 and 2, pp. 36-50.

Matanda, M.J. and Ndubisi, N.O. (2013), "Internal marketing, internal branding, and organisational outcomes: the moderating role of perceived goal congruence", Journal of Marketing Management, Vol. 29 Nos 9-10, pp. 1030-1055.

Memon, M.A., Salleh, R., Noor, M., Baharom, R. and Teknologi, U. (2017), "The mediating role of work engagement between pay satisfaction and turnover intention", IIUM Journal of Economics and Management, Vol. 25 No. 1, pp. 43-69.

Mulki, J.P., Jaramillo, F. and Locander, W.B. (2006), "Emotional exhaustion and organizational deviance: can the right job and a leader's style make a difference?", Journal of Business Research, Vol. 59 No. 12, pp. 1222-1230.

Mullen, J.E. and Kelloway, E.K. (2013), "The effects of interpersonal customer mistreatment on employee retaliation", International Journal of Workplace Health Management, Vol. 6 No. 2, pp. 118-128.

Netemeyer, R.G., Boles, J.S. and Mckee, D. (1997), "An investigation into the antecedents of organizational citizenship behaviors in a personal selling context", Journal of Marketing, Vol. 61 July, pp. 85-98.

O'Reilly, C.A., Chatman, J. and Caldwell, D.F. (1991), "People and organizational culture: a profile comparison approach to assessing person-organization fit", Academy of Management Journal, Vol. 34 No. 3, pp. 487-516.

Podsakoff, P.M., MacKenzie, S.B., Lee, J.Y. and Podsakoff, N.P. (2003), "Common method biases in behavioral research: a critical review of the literature and recommended remedies", Journal of Applied Psychology, Vol. 88 No. 5, pp. 879-903.

Reynolds, K.L. and Harris, L.C. (2006), "Deviant customer behavior: an exploration of frontline employee tactics", Journal of Marketing Theory and Practice, Vol. 14 No. 2, pp. 95-111.

Robinson, S.L. and Bennett, R.J. (1995), "A typology of deviant workplace behaviors: a multidimensional scaling study", Academy of Management Journal, Vol. 38 No. 2, pp. 555-572.

Saks, A.M. and Ashforth, B.E. (1997), "A longitudinal investigation of the relationships between job information sources, applicant perceptions of fit, and work outcomes", Personnel Psychology, Vol. 50 No. 2, pp. 395-426.

Schepers, J. and Nijssen, E.J. (2018), "Brand advocacy in the frontline: how does it affect customer satisfaction?", Journal of Service Management, Vol. 29 No. 2, pp. 230-252.

Schwepker, C.H. (2019), "Strengthening customer value development and ethical intent in the salesforce: the influence of ethical values person-organization fit and trust in manager", Journal of Business Ethics, Vol. 159 No. 3, pp. 913-925.

Singh, J. (2000), "Performance productivity and quality of frontline employees in service organizations", Journal of Marketing, Vol. 64 No. 2, pp. 15-34.

Singh, R. (2019), "Engagement as a moderator on the embeddedness-deviance relationship", International Journal of Organizational Analysis, Vol. 27 No. 4, pp. 1004-1016.

Sliter, M., Jex, S., Wolford, K. and Mcinnerney, J. (2010), "How rude! Emotional labor as a mediator between customer incivility and employee outcomes", Journal of Occupational Health Psychology, Vol. 15 No. 4, pp. 468-481.

Swimberghe, K., Jones, R.P. and Darrat, M. (2014), "Deviant behavior in retail, when sales associates "Go Bad" Examining the relationship between the work-family interface, job stress, and salesperson deviance", Journal of Retailing and Consumer Services, Vol. 21 No. 4, pp. 424-431. 
Zhang, J. and Bloemer, J.M.M. (2008), "The impact of value congruence on consumer-service brand relationships", Journal of Service Research, Vol. 11 No. 2, pp. 161-178.

Zheng, W., Wu, Y.C.J., Chen, X.C. and Lin, S.J. (2017), "Why do employees have counterproductive work behavior? The role of founder's Machiavellianism and the corporate culture in China", Management Decision, Vol. 55 No. 3, pp. 563-578.

\section{Corresponding author}

Fenika Wulani can be contacted at: fenika@ukwms.ac.id

For instructions on how to order reprints of this article, please visit our website: www.emeraldgrouppublishing.com/licensing/reprints.htm Or contact us for further details: permissions@emeraldinsight.com 